\title{
Murabahah accounting in BNI Syariah Makassar
}

\author{
Firman Menne, Muh. Idris, Erni
}

Bosowa University, Makassar, Indonesia

Email: firman@universitasbosowa.ac.id

\section{ARTICLE INFO}

Article history

Received, August 12, 2017

Revised, September 21, 2017

Accepted, November 202017

\author{
Keywords: \\ accounting treatment \\ implementation \\ murabahah \\ syariah bank
}

\section{ABSTR ACT}

This research aims to know and analysis implementation of murabahah accounting especially of manifestation murabaha accounting in BNI Syariah. Design methodology used comparative analysis between accounting theory and practice in Syariah banking.

The result showed that the implementation of murabahah accounting on BNI Syariah Makassar has been suitable with PSAK 102 especially for recognition, measurement, recording, and disclosure, except for accounting treatment when event of arrears and receipts of arrears installments. BNI Syariah Makassar didn't give any accounting treatment. Whereas in PSAK 102 is stipulated that when there is arrears and receipts of arrear installments, the margin is recognized proportional to the cash received.

Copyright () 2017 Indonesia Prime. All rights reserved.

\section{Introduction}

The presence of Islamic banking is very beneficial for the Muslim community in Indonesia, because sharia banking is an alternative media to save or transact in accordance with the values of sharia that can keep a person from transactions forbidden in Islam, such as usury. Nevertheless, the turnover of sharia banking is still much lower which is only about 5\% compared with conventional bank turnover (OJK, 2017).

In general, Islamic banks are defined as financial intermediation whose main business provides financing and other services in traffic payments as well as money circulation whose operations are based on Islamic Shariah either in the form of sale and purchase, profit sharing or lease. But explicitly the concept of profit sharing that truly represents the concept of Islam in banking, because in addition to moving the real sector in a balanced way, also indicate the long term so that it will have a contribution to sustainable economic growth. Ideally a sharia bank is a bank that prioritizes the concept of loss and profit sharing in product development. In its development using the concept of Muamalah Islam Indonesia which is fixed by MUI through DSN (National Sharia Council), then the practice is supervised by DPS (Sharia Supervisory Board) so that will create a banking mechanism that is expected to provide objective benefit for the people of all nature.

One of sharia banking products is murabahah financing. In sharia accounting, the murabahah accounting treatment is regulated in SFAS No. 102 which governs murabahah financing which came into effect on 1 January 2008 and not only regulates accounting for sellers only, nor for buyers. This financing uses a system of sale and purchase which in principle further alleviates the customer in case not affected by the rising and falling interest rates as applicable in conventional banks.

So far, the implementation of murabahah accounting in sharia banking still refers to the old standard that is also used by conventional banking, thus allowing no difference in the application in it. While the purpose of murabahah accounting and sharia accounting in general as far as possible can provide a fundamental difference in comparison with conventional as in the case of recognition, measurement, presentation, and disclosure murabahah transactions.

BNI Syariah Makassar is one of Syariah bank in Indonesia which runs murabahah concept that contracts sale and purchase of goods at the sale price at acquisition cost in added profit agreed that seller must express the cost of acquisition of goods to the buyer. 


\section{LITERATURE REVIEW}

\section{Sharia Bank}

Sharia banks are banks that operate by not relying on interest. Islamic Bank or commonly referred to as a bank without interest is a financial institution/banking operational, and its products developed based on Al-Qur'an and Hadith of the Prophet SAW or in other words, sharia Bank is a financial institution whose main business provides financing and other services In payment traffic as well as money circulation whose operations are adjusted to the principles of Islamic Shari'a.

According to Antonio (2001) that in sharia banks, the contracts have worldly and ukhrawi consequences because the contract is done under Islamic law. Often customers dare to violate the agreement/agreement that has been done if the law is based on positive law, but not so if the agreement has a responsibility until yaumul qiyamah.

The philosophy of sharia banking business includes three main aspects namely objectives, pillars, and foundations that can be described in Figure 1.

1. The objectives (roof) of sharia economy that is the essential success is the achievement of welfare that includes the fulfillment of material and spiritual needs (happiness of the world and the hereafter) either individually or collectively in the nation and state.

2. The pillar of sharia economy consisting of three pillars namely a) fair by avoiding exploitation and excessive exploration and arbitrariness, b) balance in the real financial sector, and riskreturn management, social-business activity, spiritual-material aspect, And the principles of environmental benefits. c) orientation to the benefit which means to protect the safety of religious life, regeneration process, and the protection of the life, wealth and mind.

3. The foundation of Sharia Economics is a) putting the business relationship in the context of universal togetherness (ukhuwah) to achieve mutual success. b) muamalah legal rules in the economic field that guides economic activity so that always by sharia, c) Character (moral) that guides economic activities always promote goodness as a way to

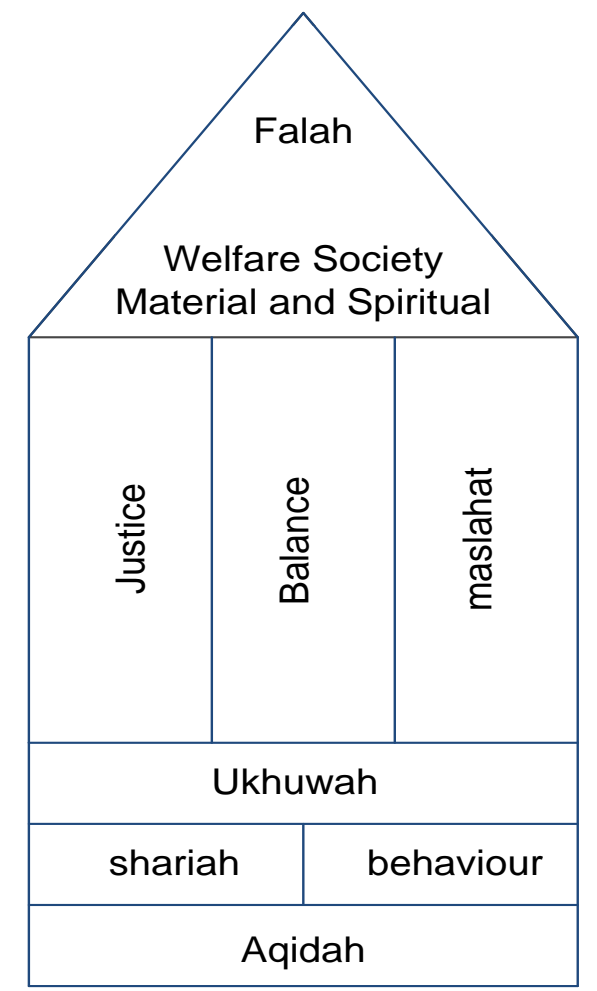

achieve goals. d) Belief in the One Supreme which raises the awareness that every human activity has accountability to foster integrity that is in line with the principles of GCG and marketing discipline.

\section{Murabahah}

According to the term, Murabahah is one form of buying and selling of goods at the price of origin with additional benefits agreed. While Murabahah comes from the Arabic word $a r-r i b h u$ which means the excess and the additional (profit) is a sale and purchase transactions where the company calls the amount of profit. The company acts as the seller, while the customer as the buyer. Selling price is the buy price of the supplier plus the profit, both parties must agree on the selling price and the terms of payment. The selling price is included in the trading agreement, and if it has been agreed, it can not be changed during the validity of the contract. Murabahah banking is usually done with installment payments (bitsamal ajil).

According to SAPK No.102, the definition of murabahah is a contract of sale and purchase of goods at the selling price of the acquisition cost plus the agreed profit, and the seller must disclose the cost of the item to the 
buyer. Under SFAS 101 (IAI, 2013) recognition and measurement of Murabahah which is as follows: 1) Accounting for Sales; At the time of acquisition, the assets Murabahah is recognized as inventory at cost. Measurement Murabahah assets after the acquisition are as follows: a) Murabahah binding orders, b) Murabahah without orders or orders are not binding. 2) Accounting For Buyers End; Debts arising from transactions recognized as a formidable Murabahah debt by the agreed purchase price (the amount to be paid). Meanwhile, according to the explanation of Nurhayati (2009) explains that in carrying out the sale and purchase activities based on the murabaha agreement there are 2 (two) types of murabaha, i.e. murabahah without order and murabahah based on order (murabahah to the purchase order).

Figure 2

Scheme Funding System Murabahah Bank Indonesia

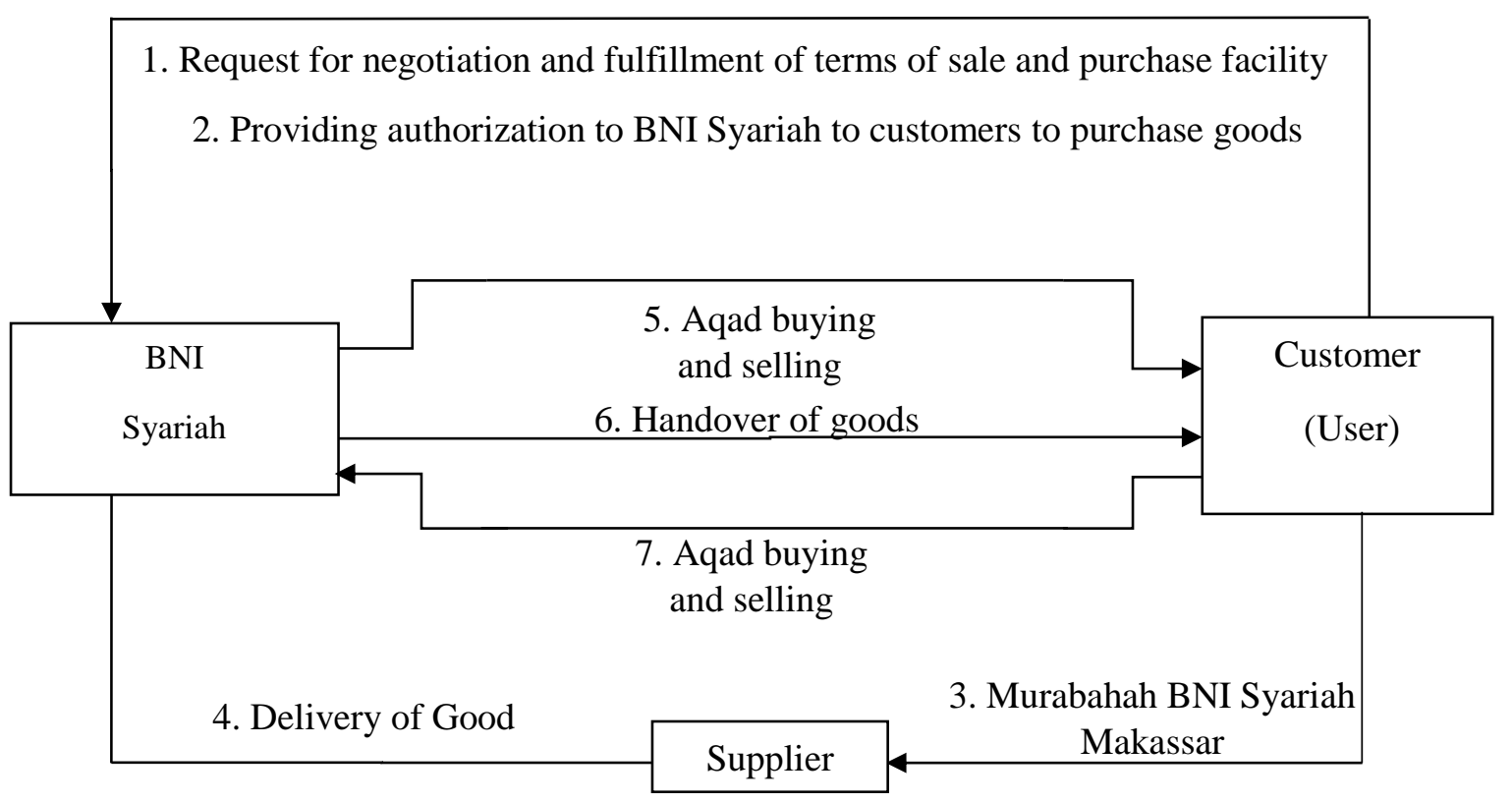

Source : BNI Syariah Makassar, 2017

Guarantee Analysis includes all deposits submitted by customers to the bank and determined the market value and the liquidation value of the guarantee. Then calculate the ratio of the guarantee to the financing with the formula of market value/liquidation value.

BNI Syariah products analyzed deeper is murabahah financing product. This product is a product of distribution of funds to the community in need and marketed by bank marketing personnel or Account Manager in charge of promoting and inviting customers to use this financing facility.

\section{Accounting Treatment}

In accordance with PSAK 102 of the Sharia Accounting Standard Board (IAI, 2013), the recognition and measurement of Murabahah are as follows:
At acquisition, murabahah asset is recognized as inventory at cost. Measurement of Murabahah assets after the acquisition is as follows:

a) If murabahah order is binding, then:

1) Rated at cost

2) In the event of any impairment in asset value due to obsolescence, damage or other conditions before being delivered to the customer, the impairment is recognized as an expense and reduced asset value

b) If murabahah without order or murabaha order not binding, then

1) Rated based on cost or net realizable value, whichever is lower.

2) If the net realizable value is lower than the cost of the acquisition, the difference is recognized as a loss. Discount of murabahah asset purchase is recognized as:

1. Accounting for Sellers. 
i. Reduced acquisition cost of murabahah assets, if occurred before murabahah agreement.

ii. The obligation to the buyer, if it occurs after the murabahah agreement and according to the agreed contract become the buyer's right

iii. Additional murabaha profits, if it occurs after the murabaha agreement and the contract agreement become the seller's rights.

iv. Additional murabahah profit, if it occurs after the murabahah agreement and according to the contract become the seller's rights.

v. Other operating income, if it occurs after the murabahah agreement and not agreed in the contract.

The seller's liability to the buyer for a refund of the purchase discount will be eliminated at the time:

a. Payments are made to the buyer at the amount of the deduction after deducting the return fee.

b. Or set as a benevolent fund if the buyer is not reachable by the seller.

At the time of murabahah agreement, murabahah receivables are recognized at the cost of murabahah asset plus the agreed benefit. At the end of the financial statements period, murabahah receivables are valued at the net realizable value, which is the balance of receivables less allowance for possible losses. Murabahah profits are recognized:

a. At the time of delivery of goods if done in cash or tough that does not exceed one year.

b. Or during the contract period by the level of risk and efforts to realize such profits for tough transactions of more than one year.

The following methods are used, and selected that best suit the risk characteristics and efforts of the murabaha transaction:

1. Gains recognized when delivery of murabahah assets. This method is applied for a strong murabaha where the risk of cash collection from murabahah receivables and management of accounts receivable and collection is relatively small. To that end, the profits will be recorded in the journal as follows:

Journal

\begin{tabular}{|l|l|l|l|}
\hline Date & Murabahah receivables & $\begin{array}{l}\mathrm{Rp} \\
\mathrm{xx}\end{array}$ & - \\
\hline & Murabahah Inventory & - & $\mathrm{Rp} . \mathrm{xx}$ \\
\hline & $\begin{array}{l}\text { Murabahah Margin } \\
\text { Income }\end{array}$ & - & Rp.xx \\
\hline
\end{tabular}

2. Gains are recognized proportionally to the amount of cash collected from murabahah receivables. This method is applied to a strong murabaha transaction where the risk of large uncollectible receivables and expenses to manage and collect receivables is relatively large as well. For that, the journal to be made when the delivery of murabahah assets and the recognition of profit margin murabaha is as follows:

a. At the time of giving murabahah asset:

\begin{tabular}{|l|l|l|l|}
\hline Date & $\begin{array}{l}\text { Murabahah } \\
\text { receivables }\end{array}$ & $\begin{array}{l}\mathrm{Rp} \\
\mathrm{xx}\end{array}$ & - \\
\hline & Murabahah Inventory & - & Rp.xx \\
\hline & $\begin{array}{l}\text { Deferred murabaha } \\
\text { margin }\end{array}$ & - & Rp.xx \\
\hline
\end{tabular}

b. Upon receipt of redemption of murabahah receivable and acknowledges the profit of murabahah in proportion to the cash it receives:

\begin{tabular}{|l|l|l|l|}
\hline Date & Cash & $\mathrm{Rp} x \mathrm{x}$ & - \\
\hline & $\begin{array}{l}\text { Deferred } \\
\text { murabaha margin }\end{array}$ & $\mathrm{Rp} . \mathrm{xx}$ & - \\
\hline & $\begin{array}{l}\text { Murabahah } \\
\text { receivables }\end{array}$ & - & $\mathrm{Rp} \cdot \mathrm{xx}$ \\
\hline & $\begin{array}{l}\text { Murabahan margin } \\
\text { income }\end{array}$ & - & $\mathrm{Rp} . \mathrm{xx}$ \\
\hline
\end{tabular}

3. Gains are recognized when all murabahah receivables are successfully collected. This method is applied to a robust murabaha transaction where the uncollectible debts and management of accounts receivable and billing are considerable. In practice, this method is rarely used, since tough murabaha transactions may not occur if there is no sufficient certainty of cash collection.

Profit recognition is proportional to the number of receivables collected by multiplying the percentage of profit on the number of 
receivables collected. The percentage of profit is calculated by comparison between the margin and the cost of murabahah asset. The deductible payment of murabahah receivables granted to buyers who repay promptly or sooner than the agreed time is recognized as a reduction of murabaha profits.

The deduction of payment of murabahah receivables can be done one of the following methods:

a. given at the time of redemption, ie the seller reduces murabaha and murabaha murabahah.

b. or awarded after repayment, i.e. the seller receives the settlement of receivables from the buyer and then pays the repayment to.

Murabahah installment deductions are recognized as follows:

a. If caused by a paying buyer promptly, it is recognized as a deduction for murabahah profit.

b. If it is caused by a decrease in the buyer's repayment capacity, it will be recognized as an expense.

Fines are imposed if the buyer is negligent in performing his obligations by the contract, and the penalty received is recognized as part of the liability fund. The recognition and measurement of advances are as follows:

1. The down payment is recognized as a down payment on the amount received.

2. If the finished goods are purchased by the buyer, then the advance is recognized as a receivable payment (an essential part)

3. If the item is void purchased by the buyer, then the advance is returned to the buyer after it is calculated with the costs incurred by the seller.

\section{Presentation}

Murabahah receivables are stated at the net realizable value, which is the amount of the murabahah receivables less allowance for losses. Deferred murabahah margin is presented as a contra account of murabahah receivables. Deferred murabahah burden is presented as a deduction (contra account) of murabahah debt.

\section{Disclosure}

Sales disclose matters relating to murabahah transactions, but are not limited to:

1) Cost of murabahah asset. Promise ordering in murabahah based on order as an obligation or not.

2) The disclosure required by SFAS 101 concerning Presentation of Sharia Financial Statements.

The buyer discloses matters related to murabahah transactions, but is not limited to:

a. The asset cash value obtained from murabahah transaction.

b. Murabahah period is tough.

\section{Research Method}

To illustrate and analyze related to murabahah financing accounting analysis based on PSAK No. 102 in BNI Syariah, a comparative descriptive method is used. This method is used to analyze crediting procedures in the reality of its application or accounting treatment in the field and to compare the existing practice in Bank Negara Indonesia Syariah with PSAK No.102 as the guidance of the rule that should followed.

\section{Results and discussion}

\section{Murabahah Financing Function}

The main function of financing is to fulfill the services to the needs of the community to encourage and launch the business activities of various fields all of which aimed at improving the living standard of the community. Murabaha products dominate sharia bank operations. So it is expected that sharia banks introspection to return to khittah. Sharia banks should reminded that the principle of profit sharing is important and should not ignored because of the principle on which it operates. The principle of sharing for the results contains great wisdom that comes from the teachings of the Prophet, which should be a guide in conducting Islamic transactions.

\section{Characteristics of Respondents}

Respondents in this study are individual taxpayers registered in PT BNI Syariah Makassar branch with the number of respondents as many as 25 people. 25 exemplary questionnaire given to the respondent has been filled completely and correctly, so it is worth to be analyzed further for 
this research. Characteristics of respondents are grouped by age, gender, last education. To clarify the characteristics of respondents in question, then presented a table on respondents as described below.

\section{Table 1}

\begin{tabular}{ccc}
\hline $\begin{array}{c}\text { Last } \\
\text { Educat } \\
\text { ion }\end{array}$ & $\begin{array}{c}\text { Frequency } \\
\text { (Person) }\end{array}$ & $\begin{array}{c}\text { Percentage } \\
(\%)\end{array}$ \\
\hline D3 & 0 & $0 \%$ \\
S1 & 17 & $68 \%$ \\
S2 & 8 & $32 \%$ \\
S3 & 0 & $0 \%$ \\
\hline Total & $\mathbf{2 5}$ & $\mathbf{1 0 0 \%}$ \\
\hline
\end{tabular}

Percentage of Respondents Age

Source: Data processed, 2017

From the data characteristic of respondents by age in Table 1 above, the largest number of respondents are respondents aged 2130 years that is as many as 12 people or $48 \%$. While the lowest number of respondents are respondents aged 41-50 years as many as 5 people or $20 \%$. So it can be concluded that most employees of the Office of PT BNI Syariah Makassar branch are aged 21-30 years.

Table 2

\begin{tabular}{ccc}
\hline Sex & $\begin{array}{c}\text { Frequency } \\
\text { (Person) }\end{array}$ & $\begin{array}{c}\text { Percentage } \\
(\boldsymbol{\%})\end{array}$ \\
\hline Men & 13 & $52 \%$ \\
$\begin{array}{c}\text { Wom } \\
\text { en }\end{array}$ & 12 & $48 \%$ \\
\hline Total & $\mathbf{2 5}$ & $\mathbf{1 0 0 \%}$ \\
\hline
\end{tabular}

Respondents by Sex
Source: Data processed, 2017

From the data characteristic of respondents by sex in Table 2 above, then the largest number of respondents are respondents of the male sex is as much as 1orang or $52 \%$. While the lowest number of respondents are female respondents which are as many as 12 people or $48 \%$. So it can be concluded that most employees of PT BNI Syariah Makassar branch are male sex.

Table 3

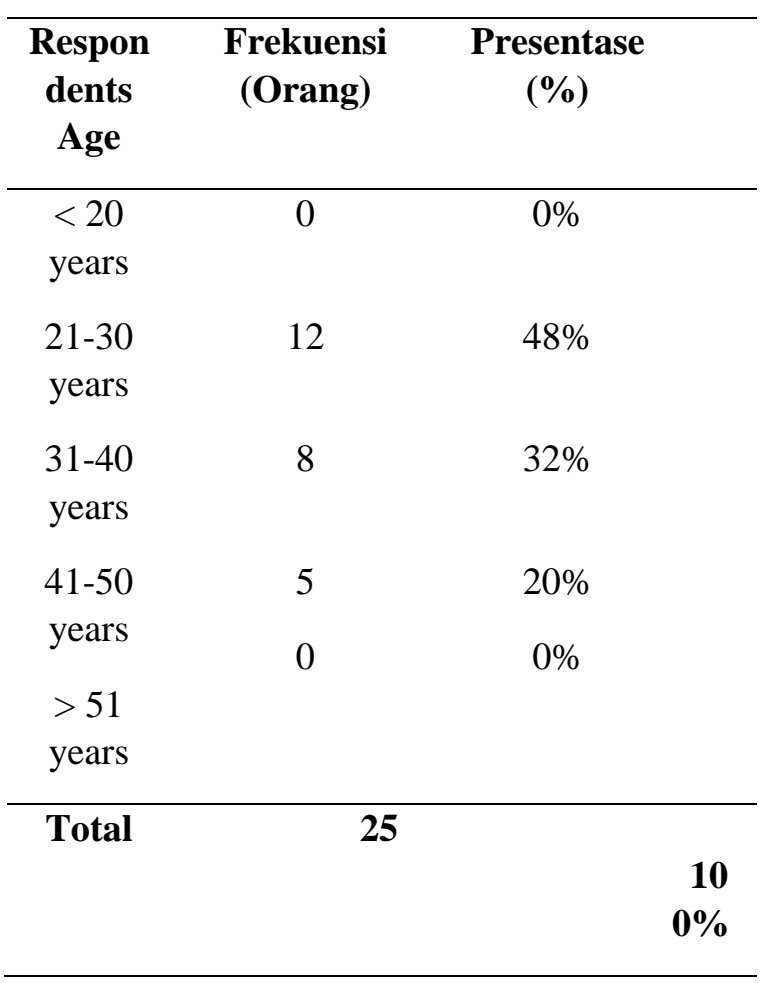

Last Education Respondent

Source: Data processed, 2017

From the respondent characteristic data based on the last education in Table 3 above, the largest number of respondents are $\mathrm{S} 1$ respondents that are 17 people or $68 \%$. While the lowest number of respondents is the respondents who $\mathrm{S} 2$ is as many as 8 people or $32 \%$. It can conclude that most of PT BNI Syariah's career in Makassar branch is an undergraduate degree.

\section{Recognition}

By SFAS 102 par.18, murabahah assets are recognized as inventories. Bank BNI Syariah acknowledges murabahah assets as a supply after the buyer shows proof of payment of down 
payment made directly to the seller (in this case the owner of the building) and the bank will credit the cash.

In BNI Syariah, murabahah receivables are recognized at acquisition value plus agreed (margin) profit. BNI Syariah has a range of margin between $13 \%$ - $18 \%$ per year set by the ALCO. The ALCO party determines the range margin by looking at the BI Rate at that time and the market share. Before the bank makes a contract with the customer, the bank will settle the margin on the murabahah murder of the customer after calculating the Account Profit Ratio (APR), and if the customer is seventh, then the murabahah agreement will occur.

\section{Measurement}

PSAK 102 par. 22 states that at the time of the murabahah agreement, murabahah receivables recognized at an acquisition cost of murabahah assets plus agreed benefits. At the end of the financial statements period, murabahah receivables valued at the net realizable value, i.e. outstanding balance less allowance for losses. BNI Syariah acknowledges and measures the murabahah receivables at the cost of the assets plus the agreed profits.

At the time of the agreement, the bank's profits are known and included in the murabaha margin suspended because they have not realized yet. In recognition and recording of murabahah receivables at the time of the contract, BNI Syariah recognizes murabahah receivables at an acquisition cost of murabahah assets plus agreed benefits.

According to PAPSI 2003 (page V.2, section 5.C.b.1b, c, d, e) states that if installments make the repayment of murabahah receivables, then the murabahah margin income is recognized when the installment is due. If in transaction murabahah part of the fund to buy come from a customer of buyer hence accounting treatment to likewise and according to accounting treatment urbun (down payment). The amount of murabaha margin is an agreement between the seller and the buyer and can be calculated, among others, by the average operational cost of the bank plus the operational profit of the bank plus the expected fair profit.

\section{Presentation}

At the end of the balance sheet period, BNI Syariah presents murabahah receivables at net realizable value, ie, murabahah receivable balances less allowance for losses. Deferred murabaha margin is presented as a deduction from murabahah receivables and is in the assets post.

\section{Conclusion}

PT BNI Syariah Makassar branch is one of syariah bank in Indonesia which runs murabahah concept that contracts sale and purchase of goods at the sale price at acquisition cost plus added profit which seller must express the cost of acquisition of goods to the buyer.

Accounting treatment Murabahah financing at PT BNI Syariah Makassar branch has been by the accounting treatment required in PSAK 102 starting from the recognition, measurement, presentation, and disclosure, except for accounting treatment when the arrears and receipt of arrear installments, BNI Syariah Makassar branch does not provide any accounting treatment. While in PSAK 102 is set that when the arrears arsura arise and receipt of arrear installments, the margin is recognized proportionally with the cash received.

As for suggestions that researchers provide is BNI Syariah bias even more vigorous in promoting and introducing products Bank Syariah profitable and easier for customers and God willing more blessing. Primarily for murabahah financing products, where no party is harmed because the customer and the bank has agreed to the sale and purchase agreement at the beginning

PT BNI Syariah Makassar in particular and PT BNI Syariah Makassar in general is expected to keep on carrying out its accounting activities and the preparation of its accountant by the applicable accounting standard that is PSAK 102 to maintain trust and openness of partners (customers).

\section{References}

[1] Qur'an and its Translation. 1989. Ministry of Religious Affairs of the Republic of Indonesia, Semarang: CV. Toha Putra.

[2] A. Antonio, Muhammad Syafi'i, 2001, Bank Syariah; From Theory to Practices, Media Insani, Jakarta.

[3] Bank Indonesia, 2014, Islamic Banking Statistics, Jakarta.

[4] Composing Team of Accounting Guidelines for Indonesian Sharia Banking, 2003. 
Accounting Guidelines for Sharia Banking: PAPSI 2003. Jakarta: Ikatan Akuntansi Indonesia

[5] Indonesia Institute of Accountant (IAI), 2007, Basic Framework for the Preparation and Presentation of Sharia Financial Statements. Date of access $27^{\text {rd }}$ June 2007.

[6] Indonesia Institute of Accountant (IAI), 2013, ED PSAK 102 Murabahah Accounting, Jakarta, Graha Akuntan.

[7] Nurhayati, Sri \& Wasilah, 2009. Syariah Accounting in Indonesia, Salemba Empat, Jakarta.

[8] OJK (Otoritas Jasa Keuangan Republik Indonesia), 2017, Increased Literacy and Financial Inclusion in the Financial Services Sector for Consumers and/or Communities, Peraturan Otoritas Jasa Keuangan No. 76/POJK.07/2016

[9]

epublic of Indonesia, Undang-Undang Perbankan Syariah 2008 (UU RI No. 21 Tahun 2008), Cet 1l, Sinar Grafika, 2009

[10] Wiyono, Slamet. 2006. Easy Way to Understand Banking Accounting Under PSAK 102 and PAPSI. Jakarta : Grasindo. 